\title{
Recentrando el papel futuro de la religión: humanizar la Humanidad. El papel de la religión en la sociedad futura va a ser netamente espiritual
}

\author{
Reorienting the future role of the religión: humanize humanity. \\ The role of the religión in society of the future will be purely spiritual
}

José María Vigil*

\begin{abstract}
Resumen
El paradigma pos-religional suscita en muchas personas dudas sobre el futuro de la religiosidad y de las religiones. El autor se confronta con esa inquietud y trata de escrutar, de un modo concreto, las posibilidades de futuro de las religiones. Poniendo la vista, como punto de partida, en el ya multisecular proceso de secularización y en el nuevo y creciente fenómeno social de los «sin religión», analiza cuáles son las transformaciones profundas que se están dando en este tiempo de transición. Hace a continuación una propuesta de ampliación y reconversión antropológica del viejo concepto de espiritualidad para reconducirlo hacia el de profundidad humana. Juntando aquellas transformaciones profundas y ese nuevo concepto de espiritualidad, trata de intuir cuáles serán las dimensiones y funciones que las religiones ya no van a poder mantener en la sociedad pos-agraria adveniente, y aporta ideas y sugerencias para desplegar con creatividad la tarea central en la que las religiones deberán recentrarse y concentrarse, la de humanizar la humanidad.
\end{abstract}

Palabras-clave: religión; pos-religional; epistemología; espiritualidad; profundidad.

\begin{abstract}
The post-Religional paradigm enables emerge in many people, questions about the future of religiosity and religions. The author confronts himself with this concern and tries to control, in a concrete way, the possibilities of a future for religions. In order, and as a starting point, the current process of secularization and the new and growing social phenomenon of 'no religion', this article analyzes the profound changes that are occurring in this time of transition. Then makes a proposal for extension and conversion of the old anthropological concept of spirituality to redirect it towards human depth. In presenting these profound changes, this new concept of spirituality seeks to understand the dimensions and functions that religions are no longer able to keep in post agrarian society what is to come, contributing with ideas and suggestions to deploy creativity with the central task from which religions should reorient and focus, that is, the task of humanizing humanity.
\end{abstract}

Keywords: religion; post-Religional; epistemology; spirituality; depth

\footnotetext{
Artículo recibido el 13 de octubre de 2014 y aprobado el 12de marzo de 2015.

* Doctor en Educación, énfasis en nuevos paradigmas (Universidade La Salle de San José, Costa Rica), post-doctorado en Ciências da Religião (PUC Minas). Estudió Teología en Salamanca y Roma, y Psicología en Salamanca, Madrid y Managua. País de origen: Nicarágua. E-mail: ComisionTeologica@Latinoamericana.org
} 


\section{Introductión}

El llamado paradigma pos-religional fue propuesto por la Comisión Teológica Internacional de la EATWOT, Asociación Ecuménica de Teólogos y Teólogas del Tercer Mundo, hace algunos años, y fue debatida públicamente por primera vez en el IV Simpósio Internacional de Teologia e Ciências da Religião Religão e Cultura: Memórias e Perspectivas, de la Pontificia Universidad Católica de Minas (2011) en Belo Horizonte.

Sus ponencias, diálogo, y otros estudios que se sumaron al debate, fueron debidamente recogidos por la revista teológica de la EATWOT (2012), VOICES of the Third World, en su número monográfico de enero de 2012. En dicho número se recogía también una exposición de los elementos principales de esta propuesta de paradigma que necesitaban ulterior profundización, así como una amplia sugerencia de temas propuestos pautas, tanto para un desarrollo teórico del discernimiento al que se convocaba, cuanto como sugerencias dirigidas a la práctica de un acompañamiento del «tránsito» hacia esa futura sociedad posreligional, en el que quizá ya estemos, aun antes de que decidamos aceptar o no la propuesta.

El tiempo ha pasado rápidamente, y la recepción de la propuesta ha sido como se adivinaba- lenta, pero convincente. De hecho, no ha encontrado enemigos mayores, y no pocos sectores académicos la han acogido, la estudian, y la utilizan en sus aulas, y son incontables los grupos de base que la han tomado como material de estudio y de formación.

Ha parecido que era ya la hora de realizar un nuevo abordaje a la propuesta, convocando ahora a figuras mayores que se han destacado en diferentes continentes por su acogida de la propuesta, o por propuestas similares, abriéndonos a la vez y haciéndonos eco de propuestas o planteamientos semejantes que se dan en otras geografías religiosas no occidentales. La revista Horizonte ha acogido generosamente la propuesta de realizar un número especial sobre el tema, que se va a constituir a partir de ahora en un material de estudio de referencia obligada. 
Este articulo quiere ser simplemente una respuesta más a la propuesta, entre tantas otras, centrada esta vez en el aspecto positivo y de futuro que la propuesta pos-religional tiene, por más que, a algunos pueda sonarles a un vaticinio del fin de la religiosidad... No es ése el pensamiento de quienes formularon la propuesta. Al contrario: bien entendida, la propuesta es un llamado a profundizar en la religiosidad-espiritualidad humana, porque en la concentración en el servicio radicalmente renovado a esa espiritualidad o profundidad humana -como diremos- está el tal vez único futuro posible de las religiones. La propuesta posreligional no es un llamado al desánimo, o a la preparación del final próximo de las religiones, sino el llamado a concentrarnos en el papel futuro de la religión, que no puede ser más urgente y bienhechor: "Humanizar la Humanidad".

\section{Partiendo de la realidad}

Fieles al método latinoamericano, comenzaremos nuestra reflexión tomando pie en algunos aspectos de la realidad que nos parecen estar muy relacionados con el objetivo de nuestro estudio.

- El multisecular proceso de la modernidad secularizante. Sea éste el primer aspecto de la realidad a tener en cuenta a la hora de reflexionar sobre el papel de la religión en la sociedad del futuro. Porque parece que ese futuro va a ser plenamente profano y secular. Son ya casi tres siglos que llevamos en la historia de Occidente con un proceso ininterrumpido y creciente de secularización. De un mundo globalmente religioso, naturalmente religioso y profundamente religioso, estamos pasando a un mundo secular. Algo está pasando en el corazón del ser humano, que desarrolla una nueva sensibilidad según la cual nuestros contemporáneos buscan la validez de las cosas en sí mismas, en el mundo, al margen o más allá de los valores religiosos o sagrados de los que fueron invariablemente revestidos tradicionalmente. Nuestros antepasados «primitivos» veían toda su vida como una ocasión del encuentro con lo sagrado y latranscendencia; hoy día el ser humano moderno parece sentir con prevalencia y en algunos contextos casi con exclusividad el valor secular de las cosas en sí 
mismas, en el seculum. "Lo sagrado y lo profano [secular] constituyen dos modalidades de ser en el mundo, dos situaciones existenciales asumidas por el ser humano a lo largo de su historia" (ELIADE, 1965, p. 18).

El fenómeno de la secularización, denostado primero, revalorizado después ${ }^{1}$, y hoy sentido como proceso en marcha inconcluso, que va a profundizarse mucho más al desembocar en un proceso todavía más amplio y profundo (pos-religional), no puede sino vaticinar la urgente necesidad de confrontar las religiones con su propio futuro ante este nuevo ambiente cultural. Las religiones necesitan estar dispuestas a reconfigurar los conceptos de religión, religiosidad, espiritualidad... así como a re-imaginar su función en el nuevo contexto. Fueron concebidas en un mundo no sólo religioso sino pan-religioso, y religiocéntrico, llevan esta huella original en sus genes. En el nuevo marco de la secularidad recuperada, reconvertidas, se entenderán a sí mismas posiblemente de otro modo y tendrán una función probablemente diferente.

- El nuevo fenómeno de los «sin religión» (IBGE, 2012; PEW FORUM,. 2012). El mundo humano ha sido siempre religioso. Se puede decir que el ateísmo es una «novedad histórica» reciente. Todavía a principios del siglo XX, el grupo de los no creyentes o ateos no pasaba del o' $3 \%$ de la población mundial, pero durante el siglo XX ha sido el grupo religioso que más creció ${ }^{2}$ Estimaciones últimas (PEW FORUM, 2012) cifran ese segmento de población en el 16'3\% de la población mundial, el tercer grupo «religioso», por detrás del primero (los cristianos, 31'5\%) y del segundo (el Islam, 23'2\%).

En Brasil el IBGE, sobre los datos de 2014 ha arrojado unos datos semejantes: "os sem religião são o terceiro maior grupo do cenário religioso brasileiro: $8,04 \%$ da população brasileira se declara sem religião, o que corresponde, em termos absolutos, a 15.335.510 indivíduos. Além disso, os dados

\footnotetext{
1 “A secularização vai tornando-se complexa ao longo do tempo e, após mais de quatro séculos, já não admite uma intepretação unívoca. [...] Se impõe à consciência a existência de uma positividade muito presente nesse processo de secularização. Trata-se de um fenômeno não apenas negativo - como foi considerado durante algum tempo, muito especialmente por parte do pensamento cristão mas que, pelo contrário, apresenta fazes de visibilidade que desafiam a fé, a religião e a teologia de maneira fecunda e vital". (BINGEMER; ANDRADE, 2012, p. 107-108).

${ }^{2}$ En 1900 los "no creyentes" eran un 0'2\% de la población mundial (3 millones de una población de 1619 millones), y en 2000 eran 12'7\% (778 de 6055), DAMEN, 2003. Cfr también DAMEN, 2011.
} 
revelam que os sem religião não param de crescer e apresentam uma média de crescimento continuamente superior à da população brasileira (IBGE, 2014)”3. Aunque el nombre que les es dado por el IBGE («los sin religión») no resulta adecuado ni veraz ${ }^{4}$, al IBGE le asiste toda la razón al detectar en este nuevo colectivo socioestadístico el carácter de abanderado de la transformación religiosa actual.

En EEUU, el PEW Forum (2012), reconocido think tank en materia de socioestadística religiosa, detecta el mayor colectivo religioso en EEUU, precisamente, en los ex-católicos, los 30 millones de adultos estadounidenses educados como católicos, que en la actualidad se declaran no pertenecientes a la Iglesia católica.

La relación, comparación y contraposición entre religión y espiritualidad, antes casi desconocida, se presenta hoy día cada vez más frecuente y abiertamente. Antiguamente se suponía que la religión era un cuerpo de doctrinas y conocimientos transmitidos directamente por Dios a nuestros ancestros, y que sólo ella era la identidad capaz de convalidar las prácticas personales de acceso a Dios (O'MURCHU, 1997, p. 77-78). Hoy día, por muchas partes cunde la opinión contraria a la tradicional: es la espiritualidad del ser humano la que creó las religiones, no la religión la que otorga al ser humano la posibilidad de la espiritualidad.

- Declaración de modestia epistemológica. No es nuestra pretensión afirmar que la crisis religiosa que estos elementos que acabamos de aludir evocan sean lo único que ocurre en la sociedad. Otras muchas cosas pasan, algunas de las cuales son incluso contrarias. En media humanidad la religión languidece, y en la otra media la religión está en efervescencia... Hay datos tan diferentes y hasta

\footnotetext{
3 “De 1950 a 2010 verifica-se que a média de crescimento dos sem religião é continuamente superior à da população brasileira em todos os decênios. Por isso, embora se ateste no Censo 2010 uma queda em pontos percentuais, os sem religião prosseguem em ritmo ascendente" (VIEIRA, 2015, p. 606).

${ }^{4}$ No son sin religión, sino no afiliados o des-afiliados a las instituciones religiosas, pero de ninguna manera podemos pensarlos como personas no «religiosas» en el sentido de portadoras de una profundidad «espiritual», ni siquiera en el caso de los ateos.
} 
contradictorios que todos los diagnósticos son posibles5. Nadie tiene un diagnóstico incontrovertible de lo que pasa en la realidad religiosa de nuestra sociedad mundial actual, porque no es «una» realidad religiosa, sino muchas, y muy diferentes. Al enfocarnos sobre un aspecto de la realidad, al elegir esos datos, nosotros nos guiamos por un criterio cualitativo-kairótico-evolutivo: no es el mero peso demográfico de las opciones religiosas lo que las avala, sino un elemento más bien cualitativo; no nos fijamos sólo en los elementos que están presentes en el escenario, sino en los que llevan el protagonismo y el liderazgo en la trama de la acción. Cuando en los siglos XII/XIII comenzó un tímido pero pujante desarrollo de los burgos en el mundo feudal, no era fácil pensar que aquel insignificante movimiento social -cuantitativamente mínimo- surgía con capacidad de asumir la guía de la evolución histórica, estando llamado a desarrollarse y a superar y poner fin globalmente a la sociedad feudal occidental en un futuro próximo. Cuando aparecieron las primeras agrupaciones o falansterios del socialismo utópico, nadie podía pensar que esas pequeñas células eran las portadoras de la guía del desarrollo de un poderoso movimiento socialista... Todavía hay mucha resistencia al pensamiento evolucionista - todavía medio EEUU no cree en la evolución, y está aferrado al fundamentalismo...- pero la nueva visión pan-evolutiva no cesa de confirmarse y extenderse; tiene el kairós de su parte, sin que importe que el cronos se le demore. Muchos movimientos tradicionales religiosos todavía ocupan gran parte del escenario religioso actual, están y van a estar todavía ahí tal vez por bastante tiempo, pero su tiempo-kairós se les ha acabado; les queda todavía un tiempo-cronos adicional, residual, pero la iniciativa histórica migró a otros lares y no cesa de actuar y crecer.

Valga esta reflexión para declarar que no consideramos que los aspectos de la realidad que destaca el paradigma pos-religional sean los únicos, pero que abrigamos la sospecha vehemente de que son los portadores de una novedad histórica empujada fuertemente por un nuevo kairós. Elaboramos esta reflexión desde una actitud tan convencida y arriesgada como epistemológicamente humilde

\footnotetext{
5 “La situación es tan compleja que parecen existir datos que apoyen los diagnósticos más contradictorios. De ahí que no falten razones, al menos aparentes, para toda suerte de interpretaciones y pronósticos sobre el futuro del cristianismo" (MARTín VELASCO, 1999, p. 127).
} 
y abierta a otras percepciones.

\section{Juzgar}

\subsection{La actual transformación a la luz de las ciencias de la religión}

Para juzgar esta realidad echamos mano de una herramienta interpretativa, el llamado paradigma pos-religional (EATWOT, 2012, p. 275-288), a la luz de las ciencias de la religión. Estando ampliamente documentado en internet, no vamos a desarrollar aquí su descripción; vamos simplemente a tratar evocar esquemáticamente su intuición nuclear, introduciéndola en la argumentación que queremos presentar.

La (hipó)tesis central del paradigma pos-religional se basa en la percepción/interpretación del fin del tiempo llamado «religional», es decir, de la «época agraria o neolítica», que ha sido la que, dentro de la evolución de nuestra especie, ha propiciado la aparición de las «religiones» (obviamente, y es preciso que lo recordemos, no de la religiosidad, que es coetánea con el homo sapiens desde su surgimiento).

El paradigma pos-religional cree que podemos constatar un cambio radical de época en el aspecto religioso dentro del proceso de evolución bio-antrópico, que veríamos reflejado en los siguientes rasgos:

- Ha llegado el final de la era de la sumisión. Las edades del esclavismo y el feudalismo se acabaron. La revolución moderna nos pasó a la era de la emancipación, característica, casi sinónima, de la modernidad. El ser humano moderno tiene una sensibilidad que ya no acepta espontáneamente y sin dificultad la sumisión existencial. Le cuesta considerarse destinado a «alabar, servir y reverenciar a Dios nuestro Señor y mediante esto salvar su ánima»6, como un

\footnotetext{
${ }^{6}$ El dicho es de Ignacio de Loyola, en su "Principio y Fundamento», pero es, sobre todo, el símbolo de una sensibilidad espiritual
} premoderna (en este punto, aunque Ignacio tuviera otros rasgos claramente modernos. 
esclavo ante su Señor: este lenguaje ya no es moderno ${ }^{7}$. Llevamos ya varios siglos atravesando este proceso de emancipación. El ser humano moderno actual es culturalmente consciente de su valor y dignidad, tiene una nueva autoestima, y ya no es capaz de aceptar una religiosidad que siga estando basada en el «desprecio de la criatura» y en el sometimiento total ante una supuesta divinidad todopoderosa ${ }^{8}$, en una «ontología del señorío»9, de la sumisión. No acepta una religión que, como han hecho las religiones subsiguientes a la revolución agraria, «le ponga de rodillas» ${ }^{10}$, existencialmente hablando.

- La «fe», como obsequium rationabile, sacrificium rationis, o el creer lo que no se ve, no es ya viable para el ser humano moderno actual: éste siente que incurriría en una actitud indigna de sí mismo si se plegara a unas tales exigencias de sumisión, y que sería también indigno de la humanidad un dios que le pidiera una tal sumisión existencial ${ }^{11}$. Las religiones que sigan manteniendo la sumisión existencial como la actitud central exigida al ser humano no van a ser viables en el inmediato futuro en los sectores socioculturales que hayan asumido esta transformación fundamental de la modernidad. La emergencia de la conciencia de ser sujeto, portador de una dignidad y detentador de unos derechos, la emancipación de las subjetividades, la conciencia del derecho a decidir, a decidir sobre lo que le hace bien y cómo relacionarse con lo espiritual, sin sentirse sometido obligatoria y ciegamente a lo que decidan unas mediaciones y unos mediadores religiosas. Las personas quieren ser y se sienten sujetos adultos y quieren decidir sobre su vida, no pueden aceptar que han venido para seguir un guión ya trazado, para obedecer a una autoridad humana considerada sagrada, para una prueba de sumisión (CÉSPEDES, 2015, p. 253-278).

\footnotetext{
${ }^{7}$ Ildefonso Navarro se pregunta por la actualidad de la tradición espiritual y educativa de la Compañía de Jesús: "esta tradición tiene raíces marcadas profundamente por un tipo de religiosidad que ya no responde a la situación presente y, al mismo tiempo, tiene una espiritualidad con elementos profundamente actuales". (NAVARRO, 2015, p. 617-618)

8 "Señor, soy tu esclavo, e hijo de tu esclava", reza con toda naturalidad el salmo, n. 116, 16.

${ }^{9}$ La expresión es de Marià Corbí (2007, p. 126). Expresa muy bellamente un rasgo mayor del pensamiento filosófico y religioso de la edad agraria, que ha durado hasta hoy.

${ }^{10}$ Esta expresión podría convertirse en otra metáfora de la edad agraria: lo que las religiones agrarias han hecho ha sido poner al ser humano "de rodillas», pidiéndole en ante todo la sumisión, la obediencia, la humillación. Es algo que ya no va a ser posible en con el final de la edad agraria, con el advenimiento de la sociedad moderna.

${ }^{11}$ Recordemos que la palabra Islam significa precisamente sumisión... Esta centralidad de la sumisión no es propia sólo del cristianismo, sino de no pocas religiones.
} 
Las mismas religiosas estadounidenses, agrupadas en la LCWR, mujeres bien preparadas, maduras y muy conscientes de sí, han podido decir: "Ya no somos niñas; y seguir actuando como si lo fuéramos priva al mundo y a las siguientes generaciones de nuestra aportación”. Debemos dar testimonio de lo que sabemos (SCHRECK, 2014).

- El final de la sumisión se refiere también a la sumisión hacia el pasado. En las religiones agrarias pesa mucho, por su propia naturaleza, la fuerza de la tradición, la sabiduría heredada del pasado, los sistemas religiosos que elaboraron nuestros ancestros y que han dirigido la vida de generaciones y generaciones, como una norma suprema, sagrada, divina, inmutable, inapelable... Hoy el ser humano, con todo el respeto para con su propia historia, no se siente encadenado al pasado. Ha perdido su ingenuidad respecto a ese pasado. Ha descubierto de un modo «científico» el carácter construido de las tradiciones, de los mitos religiosos y de los sistemas de creencias y doctrinas de las religiones.

- Tras un primer momento de «decepción» ingenua, se ha producido una revalorización de este patrimonio simbólico que está a la base de las religiones, pero re-considerado ahora (con una «segunda ingenuidad») y recibido con una diferente libertad de espíritu: el ser humano moderno actual no se siente encadenado al pasado, ni se cree condenado a tener que repetirlo, ni a tener que continuar asumiendo las fórmulas morales y/o «dogmáticas» de que se dotaron nuestros ancestros; nosotros tenemos el derecho y el deber de decidir sobre el sentido de nuestra vida, así como sobre nuestra moral y nuestra vía de espiritualidad. ${ }^{12}$

- Estamos también en el final de la edad de la «heteronomía», la edad de la ley venida de fuera, de otro mundo, de arriba, de un «segundo piso» que nos sobrevuela por las alturas de este mundo, y de vez en cuando deja caer un

\footnotetext{
12 “Ha llegado el momento de sobrepasar el exclusivismo religioso y la discriminación. Los ríos deben de fluir y las personas religiosas madurar, de otro modo, se estancan. Tenemos que ser creadores de la historia, no sus víctimas. No nacimos para vivir dentro de límites estrechos. Tenemos que replantear nuestros problemas en este nuevo contexto de mucha gente de otras fes" (SESHAGIRI RAO, 2010, p. 152).
} 
conocimiento que los humanos necesitamos para conducir nuestras vidas... Al ser humano moderno actual le resulta totalmente inaceptable, por incomprensible o ininteligible, la «hetero-nomía»: este mundo, este cosmos, este mismo ser humano, tiene la norma en sí mismo, y no está dependiendo de una norma que venga de fuera, o de arriba ${ }^{13}$.

- Las religiones agrarias nacieron, se desarrollaron y se han mantenido milenariamente en este esquema dualista de los dos pisos. Para ellas, el segundo piso, concebido como por encima de éste, viene a ser considerado el mundo verdaderamente real, y eterno (frente a este mundo de abajo, que viene a ser considerado como una ilusión, pasajera). Dado que ese mundo superior acapara y encierra todos los valores, nuestra espiritualidad no puede ser más que la participación en ese mundo superior divino.

- Estamos asistiendo al final de la epistemología mítica, la forma de pensar que aceptaba la validez de los mitos como forma de conocimiento, sagrado en su naturaleza, venido de los dioses, con un valor «descriptivo» de la realidad que narran o elaboran... El «gran mecanismo epistemológico» que hemos puesto en marcha los humanos para dar validez y carácter absoluto a los mitos y a sus contenidos ha sido su atribución a Dios: habrían sido por Él revelados, y serían literalmente «palabra de Dios», supremo validador del conocimiento humano. Esta atribución a Dios de nuestras elaboraciones míticas y religiosas, de nuestra moral y de nuestras formas de socialización, ha sido la forma de absolutizar y fijar nuestras formas sociales, incluidas las religiosas.

- El ser humano moderno actual ha perdido su ingenuidad, sabe que hemos construido nuestros mitos, que los hemos atribuido a Dios, y que, al absolutizarlos de esta forma, nos hemos sometido a nuestras propias creaciones, quedando así rehenes de nosotros mismos. A la vez que valora mucho, de un modo renovado, el papel que los mitos han representado en la composición de su conciencia religiosa, el ser humano moderno no acepta ya dirigir su vida ni su moral, ni su religiosidad

\footnotetext{
${ }^{13}$ Roger Lenaers, en uno de sus libros más emblemáticos, ha hecho de la «heteronomía» la categoría clave para presentar el desafío mayor de la modernidad a la religión. (LENAERS, 2008).
} 
profunda sobre la base de los principios heredados en su tradición ancestral. Las religiones que quieran seguir jugando algún papel en la conciencia del ser humano actual sólo podrán hacerlo después de una re-conversión profunda de sus bases y sus estructuras míticas. Sin esta reconversión serán rechazadas no serán siquiera escuchadas.

- Estamos asistiendo a la eclosión de una «conciencia científica» de la humanidad, que por primera vez en la historia nos proporciona a todos los pueblos de este planeta un mismo relato cosmológico de los orígenes cosmo-biológicos de nuestra especie. También por primera vez responde a la pregunta de quiénes somos con una respuesta amplia y en buena parte satisfactoria a la pregunta de dónde venimos. Los asuntos del sentido del cosmos y de nuestra vida, ancestralmente controlados en exclusiva por la religión y más tarde también por la especulación de la filosofía, han cambiado de hogar, y hoy se cocinan en el laboratorio de la ciencia. Seguimos agradeciendo la sabiduría y la espiritualidad que transpiran los mitos, creencias y doctrinas de las religiones sobre todos estos temas, pero para el ser humano moderno actual ya no son las palabras más válidas para desvelarnos el sentido de lo que lo que somos. Estamos en una sociedad profundamente marcada por la ciencia. La religión y la filosofía pueden ser y son tenidas en cuenta, pero sólo en un modo complementario y subsidiario. El libro de la Revelación religiosa ha dejado su puesto de primacía al «primer libro», el de «la creación», o en lenguaje secular, al libro de la realidad, accedido por la ciencia, a la que se le reconoce hoy un «valor revelatorio» (BERRY; CLARKE, 1997, p. 19ss).

Los creyentes más avanzados están reconociendo el valor al «Primer Libro» y devolviéndole su primacía y prioridad, y, de un modo irreversible, se sienten profundamente comprometidos con esta edad científica, sintiendo a la ciencia como la base de nuestro conocimiento, la principal extensión de nuestros ojos, la fuente más fecunda de admiración y de éxtasis contemplativo...

- Una religiosidad basada exclusivamente en el segundo libro -como lo ha sido hasta ahora, y no sólo con carácter de exclusiva, sino de primacía y 
contradicción- ya no es viable para los seres humanos modernos actuales. Una religión que todavía crea tener una fuente exclusiva de percepción de verdades propias (eternas, reveladas, o proclamadas dogma, o declaradas irreformables...) que entren en competencia con las verdades de las ciencias humanas, una religión que exija al ser humano creer ante todo «lo que la Santa Madre Iglesia nos propone» o lo que dicte el Magisterio -único intérprete autorizado de la Sagrada Escritura ${ }^{14-}$, con prioridad incuestionable sobre la ciencia, estará exigiendo al ser humano actual un asentimiento que éste ya no está en capacidad de otorgar.

- Estamos asistiendo a la metamorfosis de la religiosidad por antonomasia, la de la percepción de lo sagrado... Rudolf Otto (1996) pudo estar muy acertado en su tiempo, no tan lejano, pero el acelerado proceso de secularización y la consecuente transformación de la religiosidad deja entrever que los seres humanos modernos no sienten ya «lo sagrado» en aquellos términos de tremens et fascinans... El mismo Mircea Elíade, posterior, ya intuyó que las cosas estaban dejando de ser así.

Y no sólo lo sagrado, sino la religiosidad como tal, en todas sus dimensiones, está experimentando una verdadera «metamorfosis» (MARTíN VELASCO, 1999). Los humanos actuales vamos accediendo a una cartografía espiritual distinta; no sentimos ni percibimos la dimensión religiosa como antaño, ni como hace sólo unas pocas décadas: la vivencia espiritual humana se está metamorfoseando, y no sabemos en qué tipo de transformación vamos a experimentar. Tal vez ya están presentes las nuevas (futuras) formas religiosas hacia las que vamos, y no sabemos reconocerlas...

- A las religiones que tengan la flexibilidad y humildad necesaria, les tocará aceptar re-convertirse radicalmente. Deberán abandonar todo aquel bagaje «agrario y neolítico» que continúan arrastrando consigo, y acompañar la evolución espiritual del ser humano en su actual transformación, dispuestas a dejarse

\footnotetext{
${ }^{14}$ Pero el encargo de interpretar auténticamente la palabra de Dios escrita o transmitida ha sido confiado únicamente al Magisterio vivo de la Iglesia, cuya autoridad se ejerce en nombre de Jesucristo. Este Magisterio, evidentemente [...] que por mandato divino y con la asistencia del Espíritu Santo [...] la expone con fidelidad, y de este único depósito de la fe saca lo que propone que se debe creer como divinamente revelado. (IGLESIA CATÓLICA, 1965, DV, n. 10).
} 
sorprender en el nuevo despertar espiritual, que no sabemos por dónde exactamente amanecerá.

Sin duda, muchos otros items podrían enriquecer esta descripción de la profundidad del cambio de época que estamos atravesando. No obstante, tal vez los elencados puedan ser considerados suficientes como para confirmar la hipótesis: las religiones (agrarias o neolíticas), por la estructura propia de la religiosidad que cristalizó en ese momento de la revolución agraria, no van a poder sobrevivir a sí mismas en la nueva sociedad que va surgiendo, si no re-convierten la conciencia que tienen de sí mismas, así como los servicios que vienen prestando al ser humano.

Ante esta descripción de la transformación actual, nos preguntamos: ¿qué va a quedar del mundo tradicional de las religiones? ¿Qué servicios religiosos prestados por las religiones, ya no van a continuar siendo viables? ¿Qué va a quedar de sus funciones, de sus modos operandi, de su propio patrimonio simbólico, y sobre todo, de sus servicios al ser humano? ¿Van a continuar siquiera siendo viables las religiones agrarias, van a ser siquiera plausibles? ¿En qué medida, en qué sentido?

¿Qué queda? Es posible que mucha cosa va a caer, pero es posible también que tal vez queda todo lo principal, lo profundo de la religión, el servicio más nuclear y hondo a la profundidad humana. Todos aquellos otros servicios adventicios, sobrevenidos, digamos que «complementarios», que durante milenios desarrolló (servicios de creencias, de verdades reveladas, servicios de autoridad sagrada, de control moral de la sociedad...), van a quedar obsoletos. Pasó la edad de infancia (agraria) de la sociedad (también podríamos llamarla «edad de hierro planetaria», en palabras de Edgar Morin (et al., 2002), o el «estadio evolucionario bio-antrópico» anterior) y ya no van a ser necesarios ni siquiera aceptables esos servicios. Deberán las religiones desnudarse de ese gran conjunto de prestaciones que asumieron en la coyuntura de la transformación de las sociedades humanas con el surgimiento de la Revolución Agraria. 
La crisis actual de las religiones está siendo un llamado al despojo de esas tareas añadidas a la tarea esencial. Lo que las religiones habrán de hacer será volver al servicio esencial, abandonar todos aquellos servicios que hoy ya no son necesarios - ni aceptables- por el desarrollo evolutivo actual del ser humano (y de su/la noosfera) y por el replanteamiento de sus condiciones de base (epistemológicas por ejemplo).

¿Cuál es, cuál ha sido, cuál podría seguir siendo, ese servicio esencial, nuclear, de las religiones? Obviamente, la religiosidad misma, la espiritualidad del ser humano. Es por eso que necesitamos chequear ese concepto.

\subsection{Reconceptualización de la «espiritualidad»: profundidad humana}

Queremos repensar la espiritualidad: ¿Qué sería hoy para nosotros hoy la espiritualidad? ¿Cómo lo delimitaríamos de un modo crítico, a la altura de nuestra evolución actual?

En primer lugar se impone la necesidad de deconstruir el sentido popularmente obvio de la espiritu-alidad, como una realidad de fuera del mundo no-material (espiritual), como una realidad amundana, incorpórea, extracósmico... algo propio de un $2^{\circ}$ piso, paralelo y superior al mundo real, ya sea en el modo platónico, ya sea en el aristotélico, o sea, un segundo piso metafísico. En la línea de la búsqueda que estamos haciendo, hemos de decir que, en realidad, «la espiritualidad no es espiritual», porque tanto la palabra espiritualidad como su palabra-raíz, «espíritu», tienen un sentido profundamente equívoco, y en esa medida, inaceptable. Mejor que cambiar el significado a una palabra con tantos problemas en su sentido original, mejor es cambiar el significante mismo: buscar

otras palabras; sólo cuando éstas hayan delimitado libremente y sin trabas el concepto que buscamos, sólo entonces podremos volver a utilizar las viejas palabras, reconducidas a la referencia segura del nuevo significado.

En segundo lugar, recordemos lo que se suele decir sobre el de religión: que no tenemos ningún concepto comúnmente aceptado del mismo. Después de tanta 
tradición de estudio sobre la religión, ocurre que todavía las ciencias de la religión no hay consenso sobre cuál es la esencia de la religión; cada escuela tiene su enfoque y utiliza el concepto haciendo una acotación de su preferencia dentro de ese ampo inmenso que consideramos que es la religión, una vivencia tan inasible, tan profunda e íntima, que no hemos encontrado todavía la forma de recudirla a conceptos «claros y distintos». 15

Con la tradicionalmente llamada espiritualidad ocurre otro tanto: son infinitas las concepciones diferentes que de ella se tienen; resulta imposible delimitar el concepto de un único modo convincentemente. Todos los conceptosdelimitaciones que cada escuela quiera establecer vienen a resultar indiscutibles (serán más o menos prácticos, pero no más o menos verdaderos; también aquí, de nomínibus non est quaestio).

Nosotros desearíamos referirnos a una conceptualización amplia de espiritualidad, lo más amplia posible, que no cayera en una parcialidad de escuela. Para nosotros, espiritualidad es, en algún sentido, lo más hondo de nosotros mismos, aquello que nos hace ser lo que somos, aquello que nos hace humanos, la misma especificidad humana... Y nos hacen humanos todos, todos los «niveles» de nuestro ser complejo, por supuesto; pero hay unas dimensiones, las más profundas, que nos son características como humanos, nos son propias, y que se ubican en el nivel más profundo de nuestra humanidad y de sus necesidades más profundas. ${ }^{16}$

- Karen Armstrong habla de que ya desde nuestro origen como especie nos hemos caracterizado por una «necesidad de poner nuestra vida en contextos más amplios» (ARMSTRONG, 2005, p. 12). No nos bastaba la vida diaria, la rutina del

\footnotetext{
15 "Religion is one thing to the anthropologist, another to the sociologist, another to the Psychologist (and again another to the next Psychologist!), another to the Marxist, another to the mystic, another to the Zen Buddhist, and yet another to the Jew or Christian. As a result there is a great variety of Religions theories of the nature of religion. There is, consequently, no universally definition of Religion, and quite possibly there never will be!" (CRAWFORD, 2002, p. 3).

${ }^{16}$ En nuestro libro de Espiritualidad de la liberación (19 ediciones diferentes, disponible en la red en servicioskoinonia.org), dedicamos toda una primera parte del libro (un tercio de su extensión total) a establecer el concepto amplio de espiritualidad; sólo después, y dentro de ese amplio concepto, concretábamos los rasgos de la espiritualidad concreta a la que queríamos referirnos, la de la liberación. La edición princeps fue la de Managua. (CASALDÁLIGA; VIGIL, 1992). Para esa primera parte del libro, p 21-44.
} 
día a día, las necesidades básicas y no tan básicas...; somos unos sujetos que necesitamos sabernos con sentido, enmarcados por un contexto más amplio de sentido, y/o de amor y de fruición, y para encontrar ese sentido es para lo que muchas veces sentimos urgencia de acudir a nuestra soledad, crear un ambiente de silencio exterior (y mental) para escuchar esa palabra y ese sentimiento de sentido en nuestra profundidad, en lo más profundo de nosotros mismos.

- Los sabios aztecas respondieron a las preguntas que les hicieron los Doce Apóstoles de México: «Es por los dioses por lo que se vive»17... Los dioses, los mitos religiosos... son corporificaciones y expresiones de esas fuerzas generadoras de sentido, de espíritu, de vida... que hacen vivir al ser humano; no son algo que está fuera, ni siquiera en un segundo piso, sino algo que le hace vivir desde lo profundo. Dioses para vivir, mitos para sentir expresadamente el sentido de nuestro ser, creencias para fungir como mojones y coordenadas profundas para nuestra vida ${ }^{18}$.

- Víctor Frankl (2000; 1979) habla de que tener/sentir un sentido es la necesidad más fundamental y más profunda del ser humano. Hasta el punto de que si no es satisfecha esa necesidad, la vida se hace intolerable: una vida sin sentido es una vida sin esperanza, desesperada. Por eso es por lo que si el ser humano no descubre un sentido para su vida, se lo inventa, lo genera, aunque sea por la vía imaginativa y mítica. Sin ese sentido profundo, sin esa profundidad, ese ser humano no sería viable. El «sentido» de la propia vida fungiría como el espíritu, el aliento, el ánimus, la ruah que animaría, habitaría e infundiría vida y re-crearía continuamente esa vida humana. Esa sería su espiritualidad, su mismo sentido profundo, su profundidad.

\footnotetext{
17 "Vosotros decís que nosotros no conocemos al Señor que está cerca y con nosotros, a aquel de quien son los cielos y la tierra. Decís que no eran verdaderos nuestros dioses. Nueva palabra es ésta, la que habláis. Por ella estamos perturbados, por ella estamos molestos. Porque nuestros progenitores no solían hablar así. Ellos nos dieron sus normas de vida. Honraban a los dioses. Nos enseñaron todos los modos de honrar a los dioses. Era doctrina de nuestros mayores que es por los dioses por quienes se vive. $\mathrm{Y}$ ahora, ¿destruiremos nuestra antigua regla de vida? Es ya bastante que hayamos sido derrotados, que se nos haya impedido nuestro gobierno. iDéjennos pues ya morir, porque ya nuestros dioses han muerto!" (LEÓN PORTILLA, 1994, p. 21ss).

${ }_{18}$ "Al igual que la ciencia y la tecnología, la mitología no consiste en desentenderse de este mundo, sino en capacitarnos para vivir de forma más plena en él”. (ARMSTRONG, 2005, p. 13). Lo mismo podríamos decir de la religión en general: no sería un «instrumento» creado sin referencia al mundo, sino para vivir en él, sólo que la forma finalmente elaborada para vivir en él puede haberse encontrado en una filosofía o sabiduría que evada al ser humano de este mundo, o le haga negarlo, o despreciarlo. La intención primera radicaría en la Vida misma, que procura su sobrevivencia.
} 
- Tillich (1968), para referirse a la religión como la «dimensión de profundidad», distinguía entre lo superficial y lo profundo, los niveles de la superficie -niveles superficiales de distintos ámbitos de nuestra vida, en los que «siempre tenemos algo que decir o algo que hacer», según unos baremos ya establecidos por la familia, la sociedad, las costumbres, la cultura -, y los niveles de la profundidad personal, aquella zona en donde nadie, ni ninguna norma o costumbre nos cohíbe, allí donde estamos nosotros solos ante el silencio y la verdad, donde no caben máscaras ni fórmulas hechas, o respuestas de cortesía ya elaboradas y establecidas socialmente, porque nuestro corazón profundo se siente «absolutamente concernido» y nos exige ver, aceptar, contemplar el Misterio y entregarnos a él. Ahí, en ese silencio interior e íntimo es donde se ubican las grandes cavernas del corazón, nuestras profundas querencias y carencias, lo que nos mueve, lo que nos apasiona, lo que nos hace sentirnos ligados a la vida, a la esperanza, a la utopía... Ésa es nuestra «profundidad, lo más profundo del ser humano. Y eso es lo que, antiguamente, con una visión dualista, metafísica y menos antropológica, estuvimos expresando con la palabra: espiritualidad, nuestro propio espíritu, una fuerza interior inasible que se apodera de nosotros, nos arrolla, nos transforma y nos hace realizar maravillas de las que nunca habríamos podido pensar que fuésemos capaces. Al recordar y re-utilizar ahora esta vieja palabra, espiritualidad, sólo queremos reconducir y vincular todas aquellas vivencias que evocaba, hacia un nuevo significante, más propio y más adecuado, libre de todos los dualismos y otras connotaciones a que se ha visto asociada tradicionalmente.

La espiritualidad sería nuestra misma humanidad, su funcionamiento más íntimo y característico como seres humanos, su dimensión profunda, ese nuestro característico y caracterizante ser humanos. Espiritualidad significaría humanidad, la profundidad de nuestra humanidad personal, el conjunto de nuestras vivencias humanas más profundas y vivificantes.

Como ya hemos recordado, "profundidad» llamaba Tillich (1952, p. 56ss) a la religión, «aquello que me concierne absolutamente» (ultimate concern), la lucha 
y la pasión con que me debato ${ }^{19}$ en mi profundidad personal, en un sentido semejante al de la espiritualidad. Marià Corbí da a la espiritualidad una nueva denominación: la «cualidad humana profunda»; y en un sentido más práctico, habla también del «cultivo de la calidad humana» como el ejercicio o cultivo de (las capacidades implicadas en) la cualidad humana profunda (CORBÍ, 2007). ${ }^{20}$

No estamos pues por las definiciones o conceptuaciones restringidas de la espiritualidad, propias de las diferentes escuelas de espiritualidad, para cada una de las cuales existe un analogatum princeps una forma o una expresión concreta de esta profundidad a la que se la identifica por antonomasia con la espiritualidad: en la tradición cristiana mayoritaria ha sido la gracia santificante, el culto, la vida interior... o -en un plano ético- el amor, la moral, o la lucha por la justicia; la oración-meditación en las tradiciones orientales; la mística-éxtasis entre los cultivadores de la mística, los «estados modificados de conciencia» en las corrientes espirituales más a interioristas, o el «conocimiento silencioso» en determinadas corrientes orientales... y así en cada escuela o corriente espiritual.

Ciertamente, todas éstas que acabamos de enumerar, son dimensiones concretas, realidades, o fenómenos «espirituales»... que expresan profundidad humana, pero no dan cuenta de la profundidad global de la persona, la más honda; son realidades de espiritualidad, pero no son «la» espiritualidad de la persona, que siempre es mucho más amplia. Hablando con un distanciamiento critico y universalista, la espiritualidad debemos ubicarla en un plano antropológicamente más profundo ${ }^{21}$ y nada particular; en un campo que podríamos llamar simplemente

\footnotetext{
${ }^{19}$ Para Tillich el ser de la persona se siente espiritualmente acosado por la nada, por el no ser, en un frente triple: la angustia del sino, que en términos absolutos es la muerte; la angustia de la vaciedad, que en términos absolutos es el absurdo; y la angustia de la culpa, que en términos absolutos es la condenación. En este contexto, espiritualidad es aquello que nos hace ser, que da profundidad a nuestro ser humanos, que nos hace vivir con ternura y con pasión, nos da coraje para vivir a pesar de todas las amenazas, y nos hace ser capaces de vivir-crear sentido.

${ }^{20}$ Y de un modo más elaborado, en La sabiduría de nuestros antepasados para sociedades en tránsito. Principios de epistemología axiológica 2 (CORBÍ, 2013).

${ }^{21}$ Jon Sobrino se refiere también a la que llama «espiritualidad fundamental», anterior a la espiritualidad cristiana: “la llamamos, en su conjunto, la espiritualidad fundamental, porque atañe a todo ser humano, y a todo cristiano por ser humano». Está constituida por "actos de espíritu que de una u otra forma, por acción u omisión, realiza todo ser humano" (SOBRINO, 1990, p. 458). Nuestro libro de espiritualidad de la liberación (CASALDÁLIGA; VIGIL, 1992) dedica toda una parte a la E1, la "espiritualidad simplemente humana», propia de todo ser humano; la espiritualidad cristiana no tendrá otra esencia; será exactamente lo mismo, simplemente revestido de y expresado en categorías cristianas.
} 
civil $^{22}$.

\subsection{Elementos de la Espiritualidad-Profundidad humana}

Llegados a este punto, y para ser más concretos, hagamos un elenco de los principales elementos y vivencias que creemos que pueden ser localizados en este nivel de la profundidad o espiritualidad humana. Queremos ubicarnos -lo volveremos a explicitar- en una visión no religiosista, netamente humana, por encima de escuelas (con ello no negamos la legitimidad de las afirmaciones particulares de cada escuela, sino que las integramos en un conjunto más amplio, integrador y basalmente antropológico). Veamos ${ }^{23}$ :

[Definición: espiritualidad como profundidad]

Así pues, digamos que, para nosotros, la «profundidad» humana (espiritualidad) es/implica/abarca:

- la necesidad ya citada que experimentamos de «ponernos en contextos más amplios»: el sentido-explicación de la realidad y de la vida, la necesidad de saber (o de imaginar que sabemos) qué somos, de dónde venimos... La necesidad de ser curiosos, de preguntarnos, de admirar... es una necesidad de conexión, de no vivir aislados, de incorporar nuestro ser a un relato [story, cosmovisión] mayor...

- la necesidad que experimentamos también de un sentido interior cordial (las «grandes cavernas del corazón»: saber que esto tiene sentido, que no es absurdo, que la realidad es acogedora, no inhóspita, y que mi vida cumple un destino, es objeto de una vocación, se sabe a sí misma dotada de sentido

- una necesidad, en definitiva, de amar y ser amado [como seres simbióticos que somos], una necesidad de amor, y muchas veces «un amor a lo divino»: introducir nuestra vida en un circuito dinámico de relaciones amorosas a vueltas

\footnotetext{
22 «Espiritualidad civil» la ha llamado Carlos CABARRÚS en su Lección inaugural del curso 2014 en la Universidad Rafael Landívar de Guatemala, el 12 de febrero de 2014.

${ }^{23}$ He tratado incursionado en un tema conexo con este (VIGIL, 2005, p. 107-210).
} 
con Dios, un «amor a lo divino» (que mi amado es para mí y yo soy para mi amado, santa Teresa). O sea, necesidad de amor, pero no sólo de amor humano, sino de amor en su más alta amplitud y su más honda profundidad...

- la necesidad que experimentamos de saciar nuestro sentido fruitivo (principalmente en el campo religioso): la estética, el ritual, el canto, la poesía, el amar y el ser amados... Los actos de culto, por ejemplo, ponen en juego principalmente dimensiones estéticas... poéticas, de belleza, a través de la música, el canto, los rituales... elementos mediante los que también nos experimentamos (fruimos) nuestra ligación identitaria con nuestros ancestros sagrados o simplemente la tradición a la que sentimos que pertenecemos... Sumergirnos en una experiencia religiosa de estas características tiene mucho de sentido, sentido fruitivo y gratificante en este caso, y de sentido identitario.

- la experiencia de Dios ordinaria, la experiencia de lo sagrado, la presencia del misterio, la amistad con el amigo del alma, la vida interior, el «tratar de amistad con Dios»

- la experiencia mística (experiencia extraordinaria de Dios): estados especiales o modificados de conciencia, contemplación, arrobamiento, trances, éxtasis... sean por la vía del conocimiento silencioso... o por la vida de la aplicación positiva de metodologías propias para propiciar o provocar tales estados modificados de conciencia... (técnicas de sabiduría espiritual, por el control de la respiración, los métodos de oración, la técnica de la meditación... o mediante bebidas espiritosas o sicotrópicas, drogas que ya tomaban en los cultos de nuestros ancestros, o en los templos de los cultos mistéricos del helenismo, o que se siguen tomando, en religiones afroamericanas por ejemplo, para provocar experiencias de trance religioso...).

- la superación de la angustia que experimentamos ante la muerte ${ }^{24}$. Más: el miedo a la condenación, a la condenación eterna, que configuraron profundamente el

\footnotetext{
${ }^{24}$ Siguiendo principalmente a Freud, John Shelby Spong ve en el esfuerzo humano de superación de esta angustia el origen de la religión (SPONG, 2001, p. 57-44), cap. III: «Autoconsciência e teísmo: irmãos siameses do teísmo».
} 
ambiente cultural espiritual de toda una época (DELUMEUAU, 2009), felizmente ya superada.

Todas estas dimensiones forman parte de del «pozo espiritual» (GUTIÉRREZ, 1984) del ser humano (del «gran hondón del alma», profundidad)... de su humanidad profunda. Y es a esta humanidad profunda, a este conjunto de dimensiones y de necesidades profundas del ser humano a lo que estuvimos llamando tradicionalmente «espiritualidad». Se llamó entonces así porque, en una mentalidad dualista, se creyó que lo que «inspir-aba» al ser humano, lo que lo «anim-aba», dándole energía y solidez, no podía ser sino algo distinto y superior, algo «no material ni carnal» (dimensiones a las que se opone el espíritu), algo «espiritual», que ya no sería de este mundo cósmico, sino algo perteneciente al mundo divino...

Hoy sabemos que lo que hemos llamado en el pasado espiritualidad no es sino la dimensión profunda del ser humano, la zona profunda de su ser, la «dimensión profunda» (Tillich), el nivel profundo de la cualidad humana, la cualidad humana profunda... Creemos que todos estos podrían ser otros tantos nuevos nombres equivalentes de lo que estuvimos llamando espiritualidad, pero con una definición menos mítica, menos accidental y más esencial, una denominación que superaría las huellas dualistas y míticas que la palabra espiritualidad lleva en sus propios genes etimológicos. Se puede seguir utilizando la palabra, porque aún está consagrada, pero no debería hacerse sin la compañía correctora de una nueva denominación, actualizada, más «científica» (desde las ciencias sociales), más civil y nada religional: profundidad, profundidad humana, calidad humana profunda.

En el fondo, alimentar la «profundidad humana» es lo que hicieron siempre las religiones. Y asumieron de hecho otras muchas funciones para la supervivencia de la especie. Y, mal o bien, lo consiguieron, cumplieron su papel, nos hicieron viables, y salvaron la supervivencia de muchos pueblos y de muchas culturas. Lo hicieron con los medios de que disponían - hoy inviables -, y lo hicieron en un 
marco de condiciones epistemológicas que hoy está desapareciendo, y ha sido sustituido por otro, muy diferente, y en muchos aspectos contrario. Por nuestra parte se tratará pues de ayudar a las religiones a asumir una transformación obligada si quieren seguir siendo funcionales a la humanidad en un nuevo estadio de su evolución bio-antrópica; se tratará de ayudarles a abandonar muchas tareas que asumieron, a asumir otras nuevas, y a re-centrarse con creatividad en cometidos esenciales que tal vez siempre ejercieron, pero de una manera diferente.

Entonces, a esta altura, hagamos este balance:

$\Rightarrow$ ante la transformación evolucionaria bio-antrópica que está atravesando la realidad de la vida en este planeta (primera parte de nuestra exposición),

$\Rightarrow \mathrm{y}$ asumiendo un nuevo concepto de la profundidad humana (lo que en otro tiempo se llamó espiritualidad) como la tarea fundamental de las religiones, (segunda parte)

$\Rightarrow$ ¿cuál será la misión pos-religional de las religiones? (Actuar)

Lo visualizaremos mejor doblemente, en dos partes: qué es lo que no puede seguir (y conviene que nos dispongamos a acompañar en su gradual abandono), y qué es lo que puede y debe continuar y desarrollarse (y debemos acompañar una etapa de tránsito, ayudando a las religiones a recentrarse en ello, a reconvertirse a sí mismas a un nuevo papel).

Veamos pues qué tareas, funciones, servicios... hicieron las religiones en el tiempo agrario -que ya no tendrán cabida en esta nueva etapa evolucionaria-, y qué tareas, funciones, servicios -tradicionales o por crear- van a ser los principales, los que deben recentrar el servicio humanizador de las «religiones».

Entramos pues con ello en la parte del ACTUAR, según nuestro método latinoamericano. 


\section{Actuar. El futuro de la religiosidad y de las religiones}

\subsection{Deconstruir la religión agraria en el tiempo pos-neolítico}

A lo largo de los diferentes estadios del desarrollo de la evolución de nuestra especie, la vida nos (auto)dotó de los recursos que necesitábamos para sobrevivir. Con el surgimiento del período agrario o neolítico, las religiones fueron uno de ellos, que nos sirvió para vivir en sociedad urbana agrícola, dar cohesión y organizacionabilidad a las sociedades, potenció nuestro sentido de pertenencia, dio fuerza del derecho que posibilitó la convivencia, el sentido moral que la potenció... Gracias a ellas se pudo organizar la fuerza de trabajo para producir excedentes y organizar los primeros imperios, agrícolas...

Pero decimos que ahora que el tiempo agrario neolítico ${ }^{25}$ toca a su fin, atravesamos «un nuevo tiempo axial» ${ }^{26}$, en el que el ser humano, su cultura y su epistemología están sufriendo una profunda mutación. A las religiones no les va a caber ya ejercer papeles que ejercieron tradicionalmente, que sirvieron en su momento para vehicular su servicio a la humanidad, pero que hoy, en el nuevo ciclo bio-antrópico que se va abriendo paso, han desaparecido, o, simplemente, se han tornado inviables. ¿Cuáles son concretamente esas tareas que ya no van a continuar siendo posibles a las religiones agrarias en un tiempo post-agrario? Las religiones ya no van a poder...

\section{a) metafísica}

- seguir fundamentándose en la metafísica, estando ya en un mundo y una cultura pos-metafísicos; (CUPITT, 1997)27

- continuar siendo las abogadas de un «segundo piso», un mundo celeste o divino,

\footnotetext{
${ }^{25}$ Es un supuesto implicado en la interpretación del paradigma pos-religional del que partimos.

${ }^{26}$ Es otra manera de interpretar el mismo cambio epocal. He profundizado sobre «un nuevo tiempo axial» en el capítulo de mi libro Teología del Pluralismo Religioso (VIGIL, 2008, p. 259-278).

${ }^{27}$ Véase su capítulo 8: The End of Dogmatic Metaphysics. Su colaboración en este mismo número de HORIZONTE insiste: "I am a secular Christian, a person committed to the critical way of thinking and a person therefore for whom there is only one world, and it is this world; only one life, and it is this life" (CUPITT, 2015, p. 542). La religión debe afrontar el carácter pos-metafísico de la cultura actual.
} 
paralelo al terrestre y humano, considerando nuestro mundo humano como supervisado por fuerzas divinas que intervienen milagrosamente en el curso de las realidades terrestres o incluso en la psique o en el espíritu del ser humano ${ }^{28}$.

- continuar considerando Dios y el teísmo como la como la clave de la bóveda del firmamento religioso, como el alfa y la omega de toda la realidad. ${ }^{29}$

- continuar exhibiendo un ardiente deseo por lo sobre-natural, lo espiritual, lo amundano (fuga mundi), a la vez que un desprecio por lo natural, lo terrestre, la carne, la materia (contemptus mundi)...

- predicar la maldad de «el mundo» (considerado por el catecismo romano clásico como uno de los tres «enemigos del alma»), el «pecado original» omnicontaminante, vehiculado por la sexualidad humana según san Agustín...

- controlar la conducta del ser humano prometiéndole un cielo pos-mortal en premio a sus buenas acciones, y amenazándole con «un infierno eterno para los pecadores»30, utilizando la prioridad suprema del otro mundo para inculcar una vida moral que mire siempre para el cielo y menosprecie «los bienes perecederos de este mundo» 3 .

- continuar insistiendo en la transcendencia absoluta de lo divino, una «transcendencia» extra-cósmica, que haría de Dios un ente extra-mundano, habitante de otro piso de la realidad 32 .

\footnotetext{
${ }^{28}$ Es conocido el grito de Nietzsche acusando al cristianismo de ser «platonismo para las masas», en el prólogo de Más allá del bien y del mal (1951). Nietzsche consideraba a Platón como un cristiano antes de Cristo. Cf. SOUZA, 2009, p. 7).

${ }^{29}$ Aunque el tema tiene raíces muy antiguo en la historia de la religión, se observa en los últimos tiempos un clamor muy claro por su superación. John Shelby Spong se ha convertido en un abanderado actual del posteísmo con la proclamación de sus 12 tesis como el Ilamado a una Nueva Reforma. Véase también SPONG, 2011. En este mismo número de Horizonte acoge una nueva presentación que el obispo hace expresamente para esta revista sobre el paradigma pos-religional (SPONG, 2015, p. 112-162).

${ }^{30} \mathrm{~A}$ nivel de propuestas teológicas prácticas, no en el nivel académico o del laboratorio teológico sino de la pastoral y de la lectura accesible al pueblo de Dios, llama la atención la propuesta pionera de John Shelby SPONG, Vida Eterna. Más allá de premios y castigos, más allá de cielo e infierno, más allá de las religiones, 2014.

${ }^{31}$ Un lugar muy apropiado para verificar este desprecio de este mundo en razón del mundo superior es la Liturgia de las Horas (ESGLÉSIA CATÓLICA, 1996). Citemos solamente el himno de vísperas del común de mártir: «Porque reputando llenos de hiel los goces de este mundo, y los dulces atractivos de los placeres, alcanzó los gozos celestiales». O el himno de laudes del común de confesor pontífice: «Por haber despreciado en su corazón los bienes los bienes perecederos de este mundo, goza ahora, entre los ángeles, del premio de la eternidad».

${ }^{32}$ En sus ensayos, el ya citado Thomas Berry habla de «reconocer la legitimidad de la noción de trascendencia, pero menciona el daño concreto que ha producido. Esta noción filosófica o teológica de trascendencia divina ha hecho daño, particularmente al desligarnos de la comunión con la tierra». "Nuestro excesivo énfasis en la trascendencia nos está llevando a destruir el planeta» (BERRY; CLARKE, 1997, p. 46 y 34).
} 


\section{b) sumisión}

- someter al ser humano y ponerlo de rodillas, apelando a la supuesta voluntad de un Dios celeste que lo pide ante todo es la «fe», el «sacrificio de la razón», el obsequium rationabile, el «creer» en él ciegamente, sin pruebas ni razones (fe es creer lo que no se ve);

- continuar siendo educadoras de la sumisión, predicadoras de todas las virtudes negativas (fe, obediencia, resignación, mortificación, ágere contra, ascética...)

- permitirse continuar fundamentándose sobre «creencias», heredadas de un brumoso pasado perdido en el origen de los tiempos, creencias de aceptación obligatoria, sin demostración, por «fe»...

- vehicular sus principios sobre la base de relatos míticos ancestrales, reclamando para ellos el carácter absoluto por haber sido revelados por Dios («palabra de Dios, textos sagrados», tradiciones magisteriales...);

\section{c) epistemología}

- considerarse las «depositarias de la verdad», casi siempre «depositarias únicas» de la misma, una verdad exclusiva en cada caso, absoluta e indubitable, por revelada...

- considerarse las intérpretes únicas autorizadas de la revelación, de un modo por tanto absoluto, inapelable, que exige sumisión ciega en conciencia;

- creer en la existencia de una verdad única absoluta, respaldada por una objetividad real, ubicada en un mundo transcendente, un respaldo real objetivo que nos permite sabernos en la verdad como adaequatio res et intellectus... Pensar que se está en la verdad porque lo que pensamos está respaldado por una realidad objetiva de la que nuestro pensamiento es copia fiel... 
- concepción mágica o premoderna de la revelación (TORRES QUEIRUGA, 1987), como una condescendencia o un don que el mundo superior del segundo piso hace sobre nuestro mundo compartiéndonos un poco del conocimiento superior de que allí se goza, que nosotros necesitaremos para la consecución de nuestra salvación...

- ponerse por encima de la ciencia, creyendo saber o tener la verdad, por encima de la ciencia...

- querer seguir siendo controladoras del pensamiento de la sociedad, imponiendo o simplemente añorando una sociedad confesional, totalizante, de cristiandad o de la sharia, por ejemplo, donde la ley religiosa sea ley social y obligue a toda la sociedad, sin dejar margen para el pluralismo ni la laicidad...

- seguir funcionando como una Inquisición y continuar queriendo controlando el pensamiento de sus adherentes, amenazando e imponiendo penas de prohibición de libertad (de pensamiento, de expresión, de enseñanza, de publicación...).

- ser «religiones de verdades» 33 , con un conjunto de verdades tenido por oficial y por exigible, de obligada fe, a todos los creyentes, con su doctrina, sus dogmas... en una amalgama de posiciones filosóficas sobre diferentes temas: mundo, creación, divinidad, ser humano, futuro...

- religión con verdades, dogmas, doctrina, teología y filosofía perennes, consideradas universalmente válidas para todas las culturas... practicando y justificando la imposición cultural, el avasallamiento de los pueblos y las culturas.

- dejar de pensar, ya para siempre, que se dispone de un poder lugarteniente de la «verdad revelada», el único que puede interpretarla autorizadamente, y que

\footnotetext{
${ }^{33}$ Gandhi declaraba: «Por suerte o por desgracia, el hinduismo no tiene ningún credo oficial. Si se me pidiera definir el credo hindú, diría simplemente: buscar la verdad por medios no violentos. Un hombre puede incluso no creer en Dios y considerarse hindú. El hinduismo es, en consecuencia, la más tolerante de las religiones. Su credo lo abarca todo». Young India, 24 de abril de 1924. (GANDHI et al, 2006, p. 15).
} 
puede además encontrar nuevas verdades, declararlas dogmas 34 -de obligado acatamiento-, irreformables35, y hacerlo con fórmulas que han de mantenerse en el tiempo porque su inspiración divina las colocaría por encima de los cambios culturales o los debates humanos y las haría definitivas, eternas ${ }^{36}$.

\section{d) pluralismo}

- exclusivismo: pensar que una religión sea «la única verdadera» (todavía en nuestro siglo XXI hay religiones - o sectores de algunas religiones- que se tienen por tales, en una actitud realmente exclusivista, que persigue a quienes no se adhieren, y que pretende crear sociedades confesionales).

- inclusivismo: no será posible continuar con la posición del inclusivismo, por cuanto no deja de ser un exclusivismo disimulado o atemperado; no será posible continuar predicando que la única religión que tiene la plenitud de la salvación es la nuestra, o que las demás están en «situación salvífica gravemente deficitaria»37. Mientras nos mantengamos en el inclusivismo, no nos será posible un verdadero diálogo religioso, sino sólo un diálogo cultural38.

- no podrán mantener inmutada, por mucho tiempo, su concepción de la misión, construida sobre la visión exclusivista ya periclitada; la misión proselitista no tiene ya mucho futuro;

\footnotetext{
${ }^{34}$ Los dogmas son «veritas revelata ab Ecclesia proposita»: BECKER, 1973, p. 31.

${ }^{35}$ "Las fórmulas dogmáticas están tan íntimamente unidas a su contenido, que cualquier cambio esconde o provoca una alteración en el contenido mismo» (PABLO VI, 1967, 5 de julio). Más aún: "Las fórmulas mismas, en las que la doctrina ha sido ponderada y autorizadamente definida, no se pueden abandonar. En este punto, el Magisterio de la Iglesia no transige» (PABLO VI, 1968, 4 de diciembre). Véase también Pío XII, Humani Géneris, AAS vol. 42, p. 565-567, 1950.

${ }^{36}$ Algunos textos pueden parecernos sencillamente increíbles: «Porque por esas fórmulas de que se sirve la Iglesia para proponer los dogmas de fe, se expresan en conceptos que no están ligados a una determinada forma de cultura humana, ni a una determinada fase de progreso científico, ni a una u otra escuela teológica; sino que manifiestan... la experiencia universal y necesaria. Por eso resultan acomodadas a todos los hombres de todos los tiempos» (PABLO VI, Mysterium Fidei, 1965; PABLO VI, AAS vol. 57, p. 758, 1965). Más concretamente: "lo que durante siglos ha constituido el consentimiento común de los doctores católicos para obtener alguna inteligencia del dogma... se apoya en principios y nociones deducidos del conocimiento verdadero de los seres creados; $y$ al deducirlo le ha iluminado a la mente, como una estrella, por medio de la Iglesia, la verdad divinamente revelada» (PÍO XII, Humani Generis, AAS vol. 42, p. 566, 1950). En resumen: «El mensaje y la doctrina se deben mantener... in suo dumtaxat genere, in eodem scilicet dogmate, eodem sensu eademque sententia »... (DE ALDAMA, 1973, p. 189).

${ }^{37}$ CONGREGACION PARA A LA DOCTRINA DE LA FÉ: Declaración Dóminus lesus, del cardenal Josef Ratzinger, 2005, n 22.

${ }^{38}$ Un dialogo interreligioso nel senso stretto della parola non è possibile, mentre urge tanto più il dialogo interculturale che approfondisce le conseguenze culturali della decisione religiosa di fondo. Mentre su quest'ultima un vero dialogo non è possibile senza mettere fra parentesi la propria fede, occorre affrontare nel confronto pubblico le conseguenze culturali delle decisioni religiose di fondo. Cfr BENEDICTO XVI, 2008.
} 
- no serán aceptables por la sociedad futura aquellas religiones sin visión macroecuménica39;

\section{e) poder político}

- no podrán volver a tiempos pasados queriendo justificando el poder, el poder estatal propio, los Estados Pontificios, los Estados Islámicos, los Sacros Imperios, el reparto de tierras y sus riquezas a los príncipes cristianos, las guerras cruzadas para arrebatar a los musulmanes su posesión de Palestina, considerada ofensiva del honor de Dios, la conquista y la sumisión de pueblos enteros y sus territorios con la sola justificación de la extensión de la Sancta Fé Catholica, el rechazo del Risorgimento italiano y del derecho de Italia a ser un país...

\section{f) oikocentrismo}

- continuar manteniendo la desacralización creacional del mundo al declararlo «no divino» por medio del mito-principio de la creación...

- continuar inculcando al ser humano su carácter principal de ser «sobre-natural», no surgido de abajo sino venido de arriba, no descendiente de esta tierra y de la evolución biológica, sino venido directamente de Dios (venido de afuera, por la creación exclusiva de Dios en el día $6^{0}$ de la creación);

- continuar manteniendo al ser humano de espaldas a la naturaleza, mediante una religión en la que no tiene presencia la naturaleza: ni en la biblia, ni en el credo, ni en los mandamientos, ni en los sacramentos, la liturgia, la eucaristía...

- continuar siendo «la religión más antropocéntrica del mundo» (WHITE, 1967, p. 1203-1207), y lavarse las manos frente a los destrozos que el antropocentrismo de la tradición judeocristiana ha producido a través de los medios modernos de la expansión territorial del capitalismo occidental;

\footnotetext{
${ }^{39}$ Sobre el macroecumenismo, el texto de referencia continúa siendo CASALDÁLIGA; VIGIL, 1992, p. 218-226.
} 
- continuar sin desmontar el «especismo» que conlleva el cristianismo, que sólo recientemente hemos sido capaces de percibir;

- continuar sin releer todo su capital simbólico desde la perspectiva de la ecología profunda...

\section{g) teísmo}

- continuar siendo las propagadoras por excelencia del teísmo, habiendo considerado como primer paso de la religiosidad lo que simplemente es un modelo de «imaginar» a Dios...

- no esforzarse por dar a los no creyentes la buena noticia del carácter de «modelo» (no absoluto por tanto) que el teísmo tiene; continuar combatiendo al ateísmo (posteísmo) si esforzarse por reconocer la verdad que encierra.

De todos estos temas no se trataría sólo de ir púdicamente olvidándonos de ellos, abandonándolos por desuso, sin demasiado ruido... sino de denunciarlos y combatirlos, no sólo por su carácter obsoleto sino sobre todo por su carácter dañino...

\subsection{Humanizar la humanidad, la nueva entidad/tarea religiosa, ya no religional}

Si hablamos de "profundidad humana» o cualidad humana como la nueva denominación de lo que habíamos venido llamando espiritualidad, es claro que estamos hablando entonces de una espiritualidad no religiosa, simplemente humana, propia del ser humano en cuanto tal, antes de cualquier adhesión religiosa confesional.

El ser humano, obviamente, no está al servicio de las instituciones religiosas, ni de los sistemas religiosos, sino al contrario. Esto supuesto, ¿cuál sería el papel de una religión que llegara a captar esta nueva perspectiva de la espiritualidad como «profundidad» humana, a cuyo servicio debiera de estar? Creemos que una religión 
dispuesta a ponerse al servicio del ser humano, al servicio de su humanización profunda, debería proponerse, como religión, tareas como las siguientes:

\section{a) Emancipación}

- poner al ser humano de pie, levantándolo de la posición de arrodillado en la que lo ha tenido siempre puesto la religión agraria: alimentar la conciencia de su valor, liberarlo de la culpa y de todas las virtudes negativas (sumisión, obediencia, resignación, amor a la cruz, mortificación...). No considerar ya, como «principio y fundamento», la sumisión inherente al ser «criado para servir, alabar y reverencias a Dios nuestro Señor, para mediante ello salvar su ánima...»;

- proclamar al ser humano moderno que Dios «no juega al escondite»; que no le pide «creer en él», como la gran prueba, ni le prohíbe dudar bajo pena de incurrir en un pecado contra la fe...

- proclamar que la fe no es la virtud máxima, que la profundidad humana religiosa no se basa en creer, en aceptar lo que no se ve, ni en dar adhesión obligada a un sistema de creencias milenario y deudor de un sistema cultural limitado y con graves fallas epistemológicos de fondo...

- proclamarle que la sumisión obligada a una divinidad extracósmica no es el resumen de sus deberes ni la esencia de su dimensión religiosa...

- Proclamar la desabsolutización del teísmo: si en los milenios pasados se creyó que el teísmo era la primera condición, sine qua non, dar ahora la buena nueva de que puede ser no teísta, no creer en theos, y vivir en un amor apasionado con la Realidad profunda, entendida como Dios en un modo nuevo (KEARNEY, 2010). El teísmo es solamente un modelo concreto -entre otros- de representación del Misterio.

- Propiciar la reconciliación con las diversas corrientes del humanismo que se ha declarado ateo ante la intemperancia del teísmo metafísico proclamado por el 
cristianismo histórico40.

- Proclamar con humildad la desabsolutización de la religión misma. Los sistemas religiosos llamados comúnmente «religiones» son construcciones humanas propias del tiempo agrario, con características deudoras de ese estadio concreto de la historia de la humanidad, construcciones que quedan obsoletas cuando se acaba esa edad y accedemos a un nuevo modelo de humanidad, y con ello a una nueva manera de ser profundamente humanos... Estamos en ese trance, y estamos llamados a vivirlo con conciencia y con libertad (CORBÍ, 1996).

\section{b) Oikocéntrico}

- devolver al ser humano a su re-encuentro con la naturaleza, en un sentido incluso sagrado: el primer libro... Homecoming, la vuelta a casa, el retorno al hogar, a nuestro oikos, a nuestra placenta natural-espiritual41. Volver allí de donde equivocadamente nos separamos ${ }^{42}$. Más que ciudadanos del cielo, sentirnos hijos de la Tierra, con una fuerte vivencia de pertenencia al Universo, nuestro hogar (CAPRA, 1991).

- Proclamar la buena noticia de la libertad: la creatividad (R)evolucionaria de la vida pasa ahora por el filum humano; le toca a este filum hacer su aportación propia con un esfuerzo de indagación y co-creatividad... (no precisamente con la sumisión y la repetición).

- Proclamar el «valor revelatorio (BERRY; SWIMME, 1994)»43 que la ciencia en general y específicamente la nueva cosmología tienen. Reconocer que la mayor fuente actual de renovación humana profunda es el propio nuevo relato cosmológico, the new story, el relato que nos dice lo que «somos» al decirnos

\footnotetext{
${ }^{40}$ Una propuesta que consideramos verdaderamente lúcida y abierta es la de Roger Lenaers, en su reciente libro Aunque no haya un dios a hí arriba, cuyo capítulo último propone El no-teísmo, como el último paso hacia el que caminamos. (LENAERS, 2013, p 195-209).

${ }^{41}$ cCf. O'MURCHU, 2011. El autor nos hace caer en la cuenta de que nuestra «historia sagrada» no es la historia de los patriarcas de Israel, ni la historia de los tres mil últimos años, sino la historia misma del cosmos y de la vida, los 13.730 millones de años, y especialmente los 3.000 millones de años del surgimiento y desarrollo de la vida en este planeta.

${ }^{42}$ Es una pregunta que actualmente cautiva y se repite cada día más: ¿Dónde fue que nos equivocamos, que perdimos el rumbo y nos fuimos por el equivocado modo de vida que nos ha llevado a la situación actual? Véase por ejemplo O'MURCHU, 2000.

${ }^{43}$ First edition con un capítulo llamativo a este respecto: The Modern Revelation.
} 
«de dónde venimos»...

- reconocer la prioridad teológica y epistemológica del «primer libro», sobre el «segundo libro»44 (San Agustín); reconocer con santo Tomás que Dios se manifiesta también por la naturaleza, y que el conocimiento (o desconocimiento) del mundo condiciona el conocimiento de Dios $45 .$.

- Proclamar la buena noticia de la espiritualidad de la materia46, la bondad del mundo (ya no enemigo del «alma») y todas sus dimensiones: la corporalidad (ya no el ágere contra, la mortificación...), la sexualidad (ya no considerada como pecado ex toto genere suo, sino como un regalo de energía y de felicidad)... De nuevo, homecoming: reconciliar al ser humano con el mundo, con la materia (O’MURCHU, 2013), con el cosmos, con la corporalidad, con la sexualidad, con la Vida, con Gaia $47 . .$.

- Proclamar el fin de todos los dualismos: cuerpo/alma, cielo/tierra, materia/espíritu... Abrirnos al holismo...

\section{c) Epistemología}

- Liberar al ser humano de la epistemología a la que lo sometió la religión agraria: no hay una verdad objetiva con fórmulas a las que «adecuar su intelecto». No hay una «voluntad de Dios» escrita en tablas de piedra, sino un Misterio Cocreador (sin alteridad respecto a nosotros, y sin teísmo) desde el que nos sentimos poderosamente atraídos a unirnos activa y creativamente a su cocreatividad...

- Abandonar el viejo concepto de una «verdad revelada fija y eterna»: no fue una revelación desde fuera, sino una muy reveladora creación de nuestros mayores

\footnotetext{
${ }^{44}$ Cf. DE LUBAC, 1952, p. 220-221. Fue ya san Agustín quien reconoció que Dios ha escrito dos libros, no uno...

${ }^{45}$ "Un error sobre el mundo redunda en un error sobre Dios»: (TOMÁS de Aquino, Summa Contra Gentiles, 1,2, c.3). También: «Una concepción equivocada acerca de las criaturas las creaturas lleva a un falso conocimiento de Dios» (TOMÁS de Aquino, Summa Contra Gentiles, II, 10). Véase: VIGIL, 2014, p. 137-146.

${ }^{46}$ iLa santa materia!, decía Teilhard de Chardin (TEILLARD DE CHARDIN, 2002) Original (póstumo): Le coeur de la matière, 1976. Véase al respecto: BOFF, La materia no existe!, 2010.

${ }^{47}$ Johana Maci se ha significado mucho en sus trabajos en esta línea inspiradora, de "Vivir como Gaia»; nuestra misión y nuestra espiritualidad debiera pretender vivir como Gaia... Tal vez su trabajo más significativo en el campo de la aplicación práctica de todo esto es MACl; BROWN, 2003. Original: Coming Back To Life. Practices to reconnect our lives, our world, 1988.
} 
en la fe, que sirvió en su momento, y todavía hoy nos inspira, pero que no puede atarnos, ni eximirnos de nuestro deber de búsqueda y de nuestra obligación de dar hoy nuestra propia respuesta en la historia...

- no se trata de creer... se trata de sentir, vibrar, de crear, y comulgar. Y eso no se puede conseguir sin indagación personal y sin optar, por nosotros mismos, arriesgándonos, no ya sometiéndonos ciegamente.

- ayudar a aceptar la incertidumbre, aceptar la realidad que hoy nos enseña la ciencia física, la imposibilidad de encontrar una respuesta «objetiva» o independiente de nosotros mismos... aceptar vivir sin verdades dogmáticas pensadas como descripciones de una realidad objetiva 48 ...

- volver a proponer la «re-recepción»49 que Schillebeeckx propuso, que continúa pendiente, pero ahora con un alcance y una urgencia mucho mayores...

- reconocer que la religión no tiene «la verdad», y que ni siquiera debe contener verdades; que no debe ser una «religión de verdades», y que fue un error fatal y una increíble arrogancia epistemológica el pensar que los jerarcas cristianos podían encontrar y proclamar dogmas, votando en sus debates conciliares, o por decisiones autocráticas del pontífice máximo... proclamando por decisión suya dogmas como afirmaciones prácticamente reveladas que a partir de entonces podía imponer en nombre de Dios... Nunca más.

- reconocer, junto con la prioridad del «primer libro», el «valor revelatorio» que las ciencias de la Naturaleza tienen para nosotros, y colocar y re-comprender en ese nuevo marco la revelación que recibimos en la historia, condicionada por nuestra ignorancia y nuestros errores sobre el mundo. Dar gracias extasiadamente (DOWD, 2005) por la Realidad inabarcable que nos permiten contemplar.

\footnotetext{
${ }^{48}$ Excelente la página de John Shelby Spong titulada: «Piensa diferente, acepta la incertidumbre», 2014.

${ }^{49}$ CONGAR (1982, p. 244ss) plantea tímida pero muy razonadamente la necesidad de proceder a una re-repción de la formulación de la fe que hemos elaborado a lo largo de la historia. Cuarenta años después, y con tantos nuevos paradigmas en curso, su propuesta parece aún mucho más tímida. Sería necesaria una re-recepción y una re-creación mucho más radicales.
} 
- que fue un error cultural-epistemológico pensar en la objetividad absoluta de la verdad, ignorando su carácter subjetivo, su carácter elaborado, sus mediaciones lingüísticas y culturales, su historicidad y su carácter de modelaciones propias de este ser viviente que es el ser humano y para su supervivencia...

- Una vez desabsolutizadas todas las religiones (no existe «la religión verdadera»), valorarlas a todas («todas son verdaderas»), con mesura y prudencia («todas son falsas»), y predisponer al ser humano a aprender de todas las religiones $5^{0}$ (escrituras, sabiduría, métodos técnicas...). Todo el patrimonio de las religiones nos pertenece a todos. Religiones están despatrimonializadas, son patrimonio de toda la humanidad).

- Poner a las religiones en alianza para salvar nuestra supervivencia, para salvar el planeta, para salvar la vida en esta Tierra51...

- Librar a las religiones de su pasión proselitista: aceptar el valor de todas las tradiciones, y dejar que sea la calidad de la profundidad humana la que vaya evolucionando de un modo que no podemos prever ni condicionar, en principio. Firmar un acuerdo macroecuménico: no hacer proselitismo entre las religiones ni ante el ateísmo consciente; tratar de ayudar simplemente a que las personas se realicen plenamente en su dimensión profunda, tomando sus propias decisiones.

\section{Conclusión}

No es cierto que el paradigma pos-religional sostenga que las religiones vayan a desparecer; eso es sólo el equivoco en que cae quien lo percibe superficialmente, o con prejuicios, o sin escuchar sus matizadas razones. Las religiones pueden continuar, deberían continuar, pero ello sólo podrá ser al precio

\footnotetext{
50 “Uno debiera ser capaz de sacar provecho de cada Escritura. Debiéramos estar agradecidos unos a otros por todas las Escrituras del mundo. Cada una de ellas es como un árbol fértil cargado de flores y frutos. No debieran ser manipuladas por motivos egoístas e individualistas. Ninguna escritura debiera usarse para infravalorar las otras" (SESHAGIRI RAO, 2010, p. 154).

${ }^{51}$ Vergonzantemente, en esta hora de emergencia planetaria, la preocupación y las propuestas para salvar la vida del planeta y de la humanidad están siendo promovidas por instancias no religiosas del mundo; las religiones parecen más preocupadas por otro mundo...
} 
de transformarse, abandonando sus prácticas «religionales»52. Muchas de las tareas que asumieron cuasi-constitutivamente en el período agrario, habrán de abandonarlas. Las religiones deberán concentrarse en la tarea esencial, que no variará: ayudar al ser humano a sobrevivir siendo cada vez más humano. Y esa tarea, aunque es la de siempre, podrá expresarse, en un gran despliegue creativo de posibilidades, como acabamos de hacer.

Aunque, por su falta de reacción ante el desafío, de hecho están retrocediendo y muriendo - las estadísticas cuantitativas y cualitativas lo testimonian-, abrigamos la esperanza de, más pronto que tarde, las religiones van a echar mano de su potencial de sintonía con la Vida y van a reconvertirse, llenas de jovialidad 53 .

Las crisis han sido parteras en la historia que han forzado y hecho posible la aparición de lo nuevo. La gran crisis actual de las religiones está forzando a las religiones a reencontrarse a sí mismas, abandonando muchas tareas que tuvieron que asumir en el período agrario y que ya no tienen sentido por el cambio radical del contexto (social, económico, cultural, evolutivo, epistemológico, filosófico, axiológico...), y, paralelamente, redescubriéndose a sí mismas, descubriendo con gozo que su vocación profunda («humanizar la humanidad») sigue siendo posible, y aun más urgente en esta nueva etapa evolutivo-bio-antrópica. Esa vocación profunda, ahora abrazada sin distracciones ni rémoras, entra dentro de lo que siempre se llamó la espiritualidad. El único futuro posible de las religiones en el tiempo pos-religional pasa por recentrarse en esta su vocación profunda de siempre: cultivar la profundidad de la humanidad, humanizar la humanizar, lo que inmemorialmente hemos llamado - con un nombre, tan añorado cuanto necesitado de superación- la espiritualidad.

\footnotetext{
${ }^{52}$ En el caso del cristianismo Lenaers afirma que, en realidad, el cristianismo originalmente no es una religión, y que, por eso, basta que vuelva a sus orígenes. Cfr. su texto en esta misma revista (LENAERS, 2015, p. 163-192). También Pierre Simón Arnold: «EL cristianismo no es una religión, sino un humanismo supra religioso", cfr.ARNOLD GULKERS, 2015, p. 78-111).

${ }^{53}$ Traté de profundizar en este desafío y esta esperanza em (VIGIL, 2013, p. 39-50.
} 


\section{REFERENCES}

ARMSTRONG, Karen. Breve historia del mito. Barcelona: Salamandra, 2005.

ARNOLD GULIKERS, Pierre Simon. ¿Un Cristianismo postreligional?. Horizonte, Belo Horizonte, v. 13, n. 37, p. 78-111, Jan./Mar. 2015. Disponible en: $<$ http://periodicos.pucminas.br/index.php/horizonte/article/view/P.21755841.2015v13n37p78>. Visitado el 31 Mar. 2015.

BECKER, Karl Joseph. La nueva interpretación de la fe. ALDAMA, J.A.; BECKER, K.J. Los movimientos teológicos secularizantes. Madrid: BAC, 1973. p. 23-47.

BENEDICTO XVI. La lettera del papa a Marcello Pera, autore di "Perché dobbiamo dirci cristiani” riprodotta in apertura del libro. 4 sept. 2008. Disponible en:

<http://chiesa.espresso.repubblica.it/articolo/209954>. Visitado el $1^{\mathrm{o}}$ de oct. 2014.

BERRY, Thomas; CLARKE, Thomas. Reconciliación con la Tierra. Santiago de Chile: Editorial Cuatro Vientos, 1997.

BERRY, Thomas; SWIMME, Brian. The Universe Story. From the Primordial Flaring Forth to the Ecozoic Era. A Celebration of the Unfolding of the Cosmos. New York: Harper San Francisco, 1994.

BINGEMER, Maria Clara; ANDRADE, Paulo Fernando Carneiro de (Org.).

Secularização: novos desafios, Rio de Janeiro: PUC-Rio, 2012.

BOFF, L. La materia no existe! Todo es energía. Servicios Koinonía. 08 oct. 2010. Disponible en: <http://www.servicioskoinonia.org/boff/articulo.php?num=402>. Visitado el 1 de octubre de 2014.

CAPRA, Fritjof. Pertencendo ao Universo. Explorações nas fronteiras da ciência e da espiritualidade. São Paulo: Cultrix, 1991.

CASALDÁLIGA, Pedro; VIGIL, José Maria. Espiritualidad de la liberación. Managua: Editorial Envío, 1992.

CÉSPEDES, Geraldina. Entrar en la danza o desaparecer de la escena. Las religiones ante los cambios de paradigma.. Horizonte, Belo Horizonte, v. 13, n. 37, p. 253-278, Jan./Mar. 2015. Disponível em:

<http://periodicos.pucminas.br/index.php/horizonte/article/view/P.21755841.2015v13n37p253>. Visitado el 31 mar. 2015.

CONGAR, Yves. Diversités et communion. Paris: Cerf, 1982.

CONGREGACIÓN PARA LA DOCTRINA DE LA FE. Declaración Dóminus Iesus. 2005. Disponible en:

<http://www.vatican.va/roman_curia/congregations/cfaith/documents/rc_con_cfaith_d oc_20000806_dominus-iesus_sp.html>. Visitado el 12 setp. 2014. 
CORBÍ, Marià. Hacia una espiritualidad laica. Sin creencias, sin religiones, sin dioses. Barcelona: Herder, 2007.

CORBÍ, Marià. La sabiduría de nuestros antepasados para sociedades en tránsito. Principios de epistemología axiológica 2. Barcelona: CETR-Bubok, 2013.

CORBÍ, Marià. Religión sin religión. Madrid: PPC, 1996.

CRAWFORD, Robert. What is Religion? London \& New York: Routledge, 2002.

CUPITT, Don. After God. The future of religion. New York: Basic Books (HarperCollins), 1997.

CUPITT, Don. A Secular Christian. Horizonte, Belo Horizonte, v. 13, n. 37, p. 542-549, Jan./Mar. 2015. Disponível em:

<http://periodicos.pucminas.br/index.php/horizonte/article/view/P.21755841.2015v13n37p542/7716>. Visitado el: 31 Marz. 2015.

DAMEN, Franz. Panorama de las religiones en el mundo 1910-2010. In: Agenda Latinoamericana Mundial 2011. Disponible en:

<http://servicioskoinonia.org/agenda/archivo/obra.php?ncodigo=707>. Visitado el 05 julio 2014 .

DAMEN, Franz. Panorama de las religiones en el mundo y en América Latina. In: Agenda Latinoamericana Mundial 2003. Disponible en:

<http://latinoamericana.org/2003/textos/castellano/Damen.htm>. Visitado el o5 julio 2014 .

DE ALDAMA, José A. El pluralismo religioso actual, en Los movimientos teológicos secularizantes. Madrid: BAC, 1973.

DELUMEAU, Jean. História do Medo em Ocidente. 1300-1800. Uma cidade sitiada. São Paulo: Companhia de Bolso, 2009.

DOWD, Michael. Thank God for the Evolution! How the Marriage of Sience and Religion Will Transform Your Life and Our World. San Francisco/Tulsa: Council Oak Books, 2005.

EATWOT's Theological Journal. Hacia un paradigma pos-religional. Propuesta teológica. VOICES, vol. 35, n. 1, p. 275-288, January/March 2012. Disponible en: <http://eatwot.net/VOICES/VOICES-2012-1.pdf>. Visitado el 22 feb. 2014.

ELÍADE, Mircea. Le sacré et le profane. Paris: Gallimard, 1965.

ESGLÉSIA CATÓLICA. Salterio del Breviario romano para cada dia de la semana: texto de la Comisión Mixta CELAM-España. Madrid: Biblioteca de Autores Cristianos, 1996. 
FRANKL, Viktor. El hombre en busca de sentido. Barcelona: Herder, 1979.

FRANKL, Viktor. En el principio era el sentido. Reflexiones en torno al ser humano. Barcelona: Paidós, 2000

GANDHI, Mahatma; KUMAR, Ravinder;María TABUYO, LÓPEZ, Agustín. Sobre el Hinduismo. Madrid: Siruela, 2006.

GUTIÉRREZ, Gustavo. Beber en su propio pozo. Salamanca: Ediciones Sígueme, 1984.

IBGE. Censo 2010: número de católica cai e aumenta o de evangélicos, espíritas e sem religião. Disponible en: < http://censo2010.ibge.gov.br/noticias-

censo ?view $=$ noticia\&id $=3 \&$ idnoticia $=2170 \&$ busca $=1 \& \mathrm{t}=$ censo-2010 - numero-catolicos-caiaumenta-evangelicos-espiritas-sem-religiao>. Visitado el 12 oct. 2014.

IGLESIA CATÓLICA. Concilio Vaticano II. Constitución Dogmática Dei Verbum sobre la Divina revelación. 1965. Disponible en:

http://www.vatican.va/archive/hist_councils/ii_vatican_council/documents/vatii_const_19651118_dei-verbum_sp.html>. Visitado el: 13 sept. 2014.

KEARNEY. Richard. Anatheism. Returning God After God. New York: Columbia University Press, 2010.

LENAERS, Roger. Aunque no haya un dios ahí arriba. Quito: Abya Yala, 2013.

LENAERS, Roger. Can Christianity and modernity go together?. Horizonte, Belo Horizonte, v. 13, n. 37, p. 163-192, Jan./Mar. 2015. Disponiblel en: <http://periodicos.pucminas.br/index.php/horizonte/article/view/P.21755841.2015v13n37p163>. Visitado el 31 Mar. 2015.

LENAERS, Roger. Otro cristianismo es posible. Fe en lenguaje de modernidad. Quito: Abya Yala, 2008.

LEÓN PORTILLA, M. El reverso de la conquista. 19. ed. México: Ed. Juan Mortiz, 1994 .

LUBAC, Henri de. Esegesi medievale. I quattro sensi della Scritta. Roma: Ed. Paoline, 1952.

MACI, Joanna; BROWN, Molly Y. Coming Back To Life. Practices to reconnect our lives, our world. New York: new Society Publishers, 1988.

MACI, Joanna; BROWN, Molly Y. Volver a la vida. Prácticas para conectar de nuevo nuestras vidas, nuestro mundo. Bilbao: Desclée de Browver, 2003.

MARTÍN VELASCO, Juan de Dios. Metamorfosis de lo sagrado y futuro del cristianismo. Disponible en: <http://servicioskoinonia.org/relat/256.htm>. Visitado el 10 sept. 2014. [Selecciones de Teología, Barcelona, n. 150, p. 127-146, 1999]. 
MARTÍN VELASCO, Juan de Dios. Metamorfosis de lo sagrado y futuro del cristianismo, Selecciones de Teología, Barcelona, v. 38, n. 150 (abril/junio 1999. Disponíble en: http://seleccionesdeteologia.net/selecciones/llib/vol38/150/150_velasco.pdf $>$. Visitado el o1 oct. 2014

MORIN, Edgar; ROGER CIURANA, Emilio; DOMINGO MOTTA, Raúl. Educar en la era planetária: el pensamiento complejo como método de aprendizaje en el error y la incertidumbre humana. Valladolid: UNESCO-Universidad de Valladolid, 2002.

NAVARRO, Ildefonso. Desde la labor educativa. In: NAVARRO, Ildefonso et al. Experiencia universitaria del estudio de la obra de Marià Corbí. Horizonte, Belo Horizonte, v. 13, n. 37, p. 614-618, Jan./Mar. 2015. Disponible en: <http://periodicos.pucminas.br/index.php/horizonte/article/view/P.21755841.2015v13n37p613/7729>. Visitado el: 31 Mar. 2015.

NIETZSCHE, F. W. Más allá del bien y del mal. Buenos Aires: Aguilar, 1951

O'MURCHU, Darmuid. Teología cuántica. Quito: Ed. Abyayala, 2013.

O'MURCHU, Diarmuid. Graça Ancestral. São Paulo: Paulus, 2011.

O'MURCHU, Diarmuid. Reclaiming Spirituality. A new spiritual framework for the today's world. New York: Crossroad, 1997.

O'MURCHU. Religion in Exile. An Spiritual Homecoming, New York: Crossroad, 2000.

OTTO, Rudolf. Lo Santo, lo Racional y lo Irracional en la idea de Dios. [original: 1917. Vers. española 1980]. Madrid: Alianza Editorial, 1996.

PABLO VI. Acta Apostolicae Sedis - AAS, vol. 57, 1965. Disponible en: <http://www.vatican.va/archive/aas/documents/AAS-57-1965-ocr.pdf>. Visitado el 12 sept. 2014 .

PABLO VI. Carta Encíclica Mysterium Fidei. 03 sept. 1065. Disponible en: <http://w2.vatican.va/content/paul-vi/es/encyclicals/documents/hf_pvi_enc_03091965_mysterium.html>. Visitado el 12 sept. 2014.

PAOLO VI. Udienza generale, Mercoledì, 5 luglio 1967. Disponible en: http://w2.vatican.va/content/paul-vi/it/audiences/1967/documents/hf_pvi_aud_19670705.html>. Visitado el 12 oct. 2014. [PAOLO VI. Insegnamenti di Paolo VI. Civitate Vaticana] : Tipografia poliglotta vaticana, 1968. vol. 5, p. 821].

PAOLO VI. Udienza generale, Mercoledì, 4 de dicembre 1968. Disponible en: <http://w2.vatican.va/content/paul-vi/it/audiences/1968/documents/hf_pvi_aud_19681204.html $>$. Visitado el 13 oct. 2014. [PAOLO VI. Insegnamenti di Paolo VI. Civitate Vaticana] : Tipografia poliglotta vaticana, 1969. vol. 6, p. 1045]. 
PEW FORUM. The Global Religious Landscape. December 18, 2012.Disponible en: <http://www.pewforum.org/2012/12/18/global-religious-landscape-exec/>. Visitado el 22 feb. 2014 .

PIO XII. Acta Apostolicae Sedis - AAS, vol. 42, p. 565-567, 1950. Disponible en: <http://www.vatican.va/archive/aas/documents/AAS-42-1950-ocr.pdf>. Visitado el 12 oct. 2014 .

PÍO XII. Carta Encíclica Humani Géneris. 12 agosto 1950. Disponible en: <http://w2.vatican.va/content/pius-xii/es/encyclicals/documents/hf_pxii_enc_12081950_humani-generis.html>.Visitado el 12 oct. 2014.

SCHRECK, Nancy. No importa cuán larga sea la noche. Asamblea de la LCWR, agosto 2014. Disponible em: <https://lcwr.org/calendar/lcwr-assembly-2014>. Visitado el: 1 de octubre de 2014 .

SESHAGIRI RAO, K.L. Teología inter-religiosa: una perspectiva hindu. In: VIGIL, José Maria (Org.). Por los muchos caminos de Dios V. Hacia una teología planetaria. EATWOT. Quito: Abyayala, 2010.

SOBRINO, Jon. Espiritualidad y seguimiento de Jesus. In: ELLACURÍA, Ignacio; SOBRINO, Jon. Mysterium Liberationis: conceptos fundamentales de la Teología de la Liberación. vol II. Madrid: Trotta, 1990. p. 449-476.

SOUZA, Mauro Araújo de. Nietizche: viver intensamente, tornar-se o que se é. São Paulo: Paulus, 2009.

SPONG, John Shelby. Piensa diferente, acepta la incertidumbre. Disponible en: <http://johnshelbyspong.es/paginas/Lateral/piensadiferente.html>. Visitado el 1 de octubre de 2014.

SPONG, John Shelby. Um cristianismo novo para um mundo novo. Campinas: Verus Editora, 2001.

SPONG, John Shelby. Un cristianismo nuevo para un mundo nuevo. Quito: Abya Yala, 2011.

SPONG, John Shelby. Vida Eterna: una nueva visión. Más allá de premios y castigos, más allá de cielo e infierno, más allá de las religiones. Quito: Abyayala, 2014.

TEILHARD DE CHARDIN, Pierre. El corazón de la materia. Santander: Sal Terrae, 2002.

TEILHARD DE CHARDIN, Pierre. Le coeur de la matière. Paris: Seuil, 1976.

TILLICH, Paul. El coraje de existir. Barcelona: Estela, 1968.

TILLICH, Paul. The Courage To Be. New Haven \& London: Yale University Press, 1952. 
TOMÁS de Aquino. Summa contra Gentiles. Torino: Casa Editrice Marietti, 1946.

TORRES QUEIRUGA, Andrés. La revelación de Dios en la realización del hombre. Madrid: Cristiandad, 1987.

VIEIRA, José Álvaro Campos. Os "sem religião": alguns dados para estimular a reflexão sobre o fenômeno. Horizonte, Belo Horizonte, v. 13, n. 37, p. 605-612, Jan./Mar. 2015. Disponible en: <http://periodicos.pucminas.br/index.php/horizonte/article/view/P.21755841.2015v13n37p605/7728>. Visitado el: 31 Mar. 2015.

VIGIL, José Maria. A jovialidade da religião/religação. Studium - Revista Teológica, Curitiba, v. 7, n. 11, p. 39-50, 2013. .

VIGIL, José Maria. Errores sobre el mundo que redundan en errores sobre Dios. Los desafíos de la nueva cosmología como tareas para la teología y la espiritualidad. Revista Fe y Pueblo, ISEAT, La Paz, vol. 25, p. 137-146, agosto 2014.

VIGIL, José Maria. ¿Que oferece la religion a la sociedad del siglo XXI. In: FUNDACIÓN JAUME BOFILL. ¿Qué pueden ofrecer las tradiciones religiosas a las sociedades del siglo XXI?: Encuentros en Can Bordoi, segundo encuentro, 28 de Junio-2 de Julio 2005. Barcelona: CETR, 2005. p. 107-120.

VIGIL, José Maria. Teología del Pluralismo Religioso. Quito: Abyayala, 2008.

VILLEDA, Oscar. Lección Inaugural 2014. Espiritualidad civil y valores, Dr. Carlos Cabarrús, S.J. Lección inaugural del curso 2014 en la Universidad Rafael Landívar de Guatemala, el 12 de febrero de 2014. Disponible en:

$<$ https://www.url.edu.gt/PortalURL/Noticias/noticia_individual.aspx? $\mathrm{n}=1022 \& \mathrm{~s}=35 \& \mathrm{c}=1$ \&nc=Academia $>$. Visitado el 13 feb. 2014.

WHITE, Lyn. The Historical Roots of Our Ecological Crisis. Science, New York, vol. 155, n. 3767, p. $1203-1207,1967$. 